
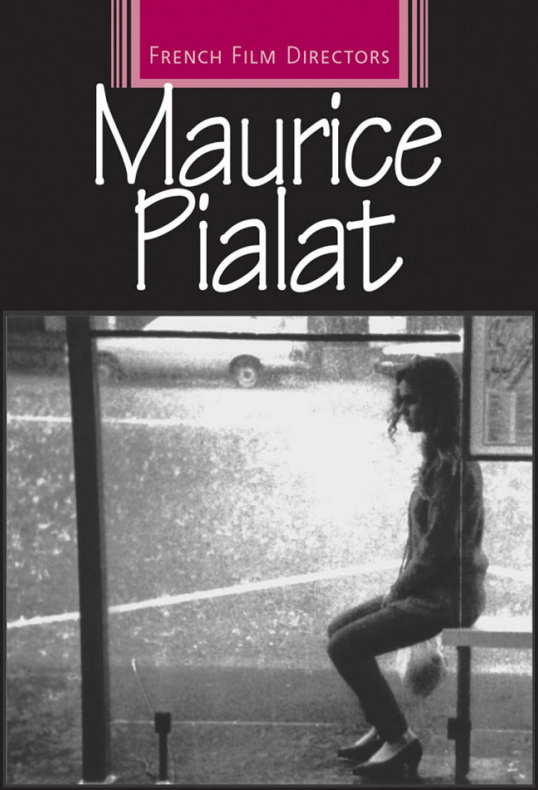

MARJA WAREHIME 


\section{Maurice Pialat}

\section{MANCHESTER 1824}

Manchester University Press 
FRENCH FILM DIRECTORS

DIANA HOLMES and ROBERT INGRAM series editors DUDLEY ANDREW series consultant

Jean-Jacques Beineix PHIL POWRIE

Luc Besson SUSAN HAYWARD

Bertrand Blier SUE HARRIS

Robert Bresson KEITH READER

Leos Carax GARIN DOWD AND FERGUS DALEY

Claude Chabrol GUY AUSTIN

Jean Cocteau JAMES WILLIAMS

Claire Denis MARTINE BEUGNET

Marguerite Duras RENATE GÜNTHER

Georges Franju KATE INCE

Jean-Luc Godard DOUGLAS MORREY

Diane Kurys CARRIE TARR

Patrice Leconte LISA DOWNING

Louis Malle HUGO FREY

Georges Méliès ELIZABETH EZRA

Jean Renoir MARTIN O'SHAUGHNESSY

Alain Resnais EMMA WILSON

Coline Serreau BRIGITTE ROLLET

François Truffaut DIANA HOLMES AND ROBERT INGRAM

Agnès Varda ALISON SMITH

Jean Vigo MICHAEL TEMPLE 
FRENCH FILM DIRECTORS

\title{
Maurice Pialat
}

\author{
MARJA WAREHIME
}

Manchester University Press

MANCHESTER AND NEW YORK

distributed exclusively in the USA by Palgrave 


\section{Copyright (C) Marja Warehime 2006}

The right of Marja Warehime to be identified as the author of this work has been asserted by her in accordance with the Copyright, Designs and Patents Act 1988 .

Published by Manchester University Press

Oxford Road, Manchester MI3 9NR, UK

and Room 400, I75 Fifth Avenue, New York, NY IooIo, USA

www.manchesteruniversitypress.co.uk

Distributed exclusively in the USA by

Palgrave, I75 Fifth Avenue, New York, NY Iooıo, USA

Distributed exclusively in Canada by

UBC Press, University of British Columbia, 2029 West Mall, Vancouver,

BC, Canada v6r IZ2

British Library Cataloguing-in-Publication Data

A catalogue record for this book is available from the British Library

Library of Congress Cataloging-in-Publication Data applied for

ISBN O 719068223 hardback

EAN 9780719068225

First published 2006

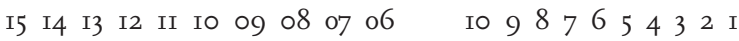

Typeset in Scala with Meta display

by Koinonia, Manchester

Printed in Great Britain

by Bell \& Bain Ltd, Glasgow 